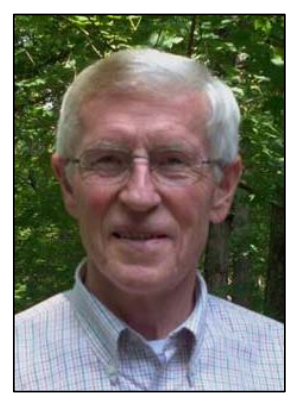

\author{
The ECONOMic Pamphleteer \\ JOHN IKERD
}

\title{
Essential principles of sustainable food value chains
}

Citation: Ikerd, J. (2011). Essential principles of sustainable food value chains. Journal of Agriculture, Food Systems, and Community Development, 1(4), 15-17. http://dx.doi.org/10.5304/jafscd.2011.014.001

Copyright (C) 2011 by New Leaf Associates, Inc.

$\mathrm{V}$ alues-based food chains include alliances of various types among farmers, processors, distributors, and other participants in food production and distribution. "Food value chains" are distinguished from conventional "food supply chains" in that relationships among participants are not solely, or even primarily, economic. Ironically, the formation of value chains is typically motivated

Why did I name my column "The Economic

Pamphleteer"? Pamphlets historically were short, thoughtfully written opinion pieces and were at the center of every revolution in western history. Current ways of economic thinking aren't working and aren't going to work in the future. Nowhere are the negative consequences more apparent than in foods, farms, and communities. I know where today's economists are coming from; I have been there. I spent the first half of my 30-year academic career as a very conventional freemarket, bottom-line agricultural economist. I eventually became convinced that the economics I had been taught and was teaching wasn't good for farmers, wasn't good for rural communities, and didn't even produce food that was good for people. I have spent the 25 years since learning and teaching the principles of a new economics of sustainability. Hopefully my "pamphlets" will help spark a revolution in economic thinking. by a quest for greater economic efficiency in the production and distribution of sustainably produced foods. However, economic efficiency cannot be allowed to take priority over the essential ecological, social, and economic principles of sustainability.

The essential ecological principles of sustainability include holism, diversity, and interdependence. Interde-

John Ikerd is professor emeritus of agricultural economics, University of Missouri, Columbia. He was raised on a small dairy farm in southwest Missouri and received his $B S, M S$, and Ph.D. degrees in agricultural economics from the University of Missouri. He worked in private industry for a time and spent 30 years in various professorial positions at North Carolina State University, Oklahoma State University, University of Georgia, and the University of Missouri before retiring in 2000. Since retiring, he spends most of his time writing and speaking on issues related to sustainability with an emphasis on economics and agriculture. Ikerd is author of Sustainable Capitalism; A Return to Common Sense; Small Farms Are Real Farms; Crisis and Opportunity: Sustainability in American Agriculture; and, just published, A Revolution of the Middle. More background and selected writings are at http://web.missouri.edu/ ikerdj. 
pendent relationships among the diverse elements of healthy natural ecosystems make the ecological wholes something more than the sum of their parts. The essential social principles of sustainability include trust, kindness, and courage. Relationships defined by contracts, regulations, or economic interests are not sustainable. People in sustainable relationships must have the courage to trust and to care about others in a world where such things are often considered idealistic and naive. The essential economic principles of sustainability include value, efficiency, and sovereignty. Sustainable economic enterprises must produce things of economic value, efficiently. They must make their own decisions and accept responsibility for their actions if they are to maintain economic viability.

The economy is a part of society and society is a part of nature. The three are also interdependent, in that each affects and is affected by the others. Thus, the same basic principles apply to all human relationships with nature and within society, which include economic relationships. Sustainable economic relationships must also reflect the principles of societies and natural ecosystems. Sustainable social relationships must also reflect the principles of economies and ecosystems. Sustainable relationships with nature must reflect the principles of societies and economies. Sustainable food value chains must have ecological, social, and economic integrity.

Rather than focusing on the economic bottom line, food value chains must focus on the triple bottom line: the ecological, social, and economic bottom lines. All economic value ultimately is derived from nature and society. However, economic value is inherently individualistic. It makes no economic sense to invest in anything solely for the good of society as a whole or for the benefit of future generations. So, sustainable food value chains must renew and regenerate the productivity of natural and human resources, even when there is no economic incentive to do so.

Triple-bottom-line management has become a popular buzz word in the business world. However, a triple bottom line that gives priority to the economic bottom line will not have the capacities for renewal and regeneration necessary for economic sustainability. Furthermore, nature and society, as living systems, are always changing and evolving.

$$
\begin{aligned}
& \text { Ever-changing } \\
& \text { government policies, } \\
& \text { market opportunities, } \\
& \text { production technologies, } \\
& \text { and public expectations } \\
& \text { are all consequences of } \\
& \text { such changes. Meeting the } \\
& \text { challenges of sustainability } \\
& \text { ultimately will require a } \\
& \text { radical rethinking and } \\
& \text { redesign of the entire food } \\
& \text { system. Sustainable food } \\
& \text { value chains must be } \\
& \text { responsive as well as renewing } \\
& \text { and regenerating. }
\end{aligned}
$$

Obviously, sustainable food value chains must be able to survive the short run if they are to thrive in the long run. Food production is a risky business. For example, the food system is affected at all levels by biological organisms that are inherently self-making, dynamic, evolving, and thus never precisely predictable. Therefore sustainable food chains must be able to withstand unexpected shocks; they must be resistant. When their resistance breaks down, as after natural disasters and major economic setbacks, they must be able to bounce back; they must be resilient. In the most severe cases, they must have a fall-back strategy or "plan B"; they must have built-in redundancy. Sustainable food value chains must be resistant, resilient, and redundant.

The essential characteristics of sustainable food value chains include renewal, regeneration, responsiveness, resistance, resilience, and redundancy - the six Rs of sustainable systems. 
Food value chains that embody the principles of ecological, social, and economic integrity will have all these essential characteristics of sustainable systems. However, maximum economic efficiency conflicts with each of these essential characteristics of sustainability.

The Panarchy theory of ecological systems dynamics was developed in the 1970 s to describe the natural behavior of ecological systems. ${ }^{1}$ It purports to explain the natural evolution of natural ecosystems. This ecological theory applies to social and economic systems as well, as economies and societies are subsets of nature. As ecosystems naturally evolve toward greater efficiency, they also evolve toward increasing "complexity," meaning an increasing number of more highly specialized functions. As systems become more complex, the internal dependencies among the specialized functions increase, which is referred to as increasing "connectivity." Increasing complexity and connectivity increase the efficiency of systems by synchronizing activities and removing redundancies both within and among the various systems functions.

However, as the dependencies are increased and redundancies are removed, ecosystems lose their resistance and resilience and their ability to respond to change. Internal dependencies allow the

\footnotetext{
${ }^{1}$ Homer-Dixon, T. (2009, March/April). Our Panarchic future. World Watch Magazine, 22(2). (Excerpted from The upside of down: Catastrophe, creativity, and the renewal of civilization, by $\mathrm{T}$. Homer-Dixon, 2006, Washington, DC: Island Press.) Excerpt retrieved from http://www.worldwatch.org/node/6008
}

consequences of outside shocks to spread through the entire system more quickly than for less "connected" systems. Lacking redundancy, efficient systems lose their ability to repel or bounce back from unexpected shocks or to respond to fundamental changes in their environment. Consequently, highly efficient systems are also highly vulnerable to collapse.

As food value chains move toward greater economic efficiency, they face the increasing risks associated with greater complexity and connectivity. Increased economic efficiency will reduce the resistance, resilience, and redundancy needed for sustainability. As investments become more narrowly focused on economic returns, such systems also will lose their capacities for renewal and regeneration, as well as the responsiveness needed for radical redesign of the food system. The need for greater economic efficiency is real, but efficiency must be balanced with the need for ecological, social, and economic integrity. Food value chains that give priority to economic efficiency may be profitable for a time, but they will not be sustainable over time. Sustainable food value chains must function in harmony and with balance among the essential ecological, social, and economic principles of sustainability. 